Acta Universitatis Wratislaviensis • No 4055

Literatura i Kultura Popularna XXVII, Wrocław 2021

https://doi.org/10.19195/0867-7441.27.17

\author{
Krystyna Walc \\ ORCID: 0000-0001-7945-5793 \\ Uniwersytet Rzeszowski
}

\title{
Kilka uwag o księgach, nie tylko uczonych, w prozie Andrzeja Sapkowskiego
}

\author{
Słowa kluczowe: Andrzej Sapkowski, książka, biblioteka, edukacja, magia
}

Keywords: Andrzej Sapkowski, book, library, education, magic

\section{Książki o/w książkach}

Pojawiające się na kartach utworów literackich książki doczekały się leksykonu. Jego autor stwierdza we wstępie:

Nie obchodzi mnie dziś, kto pierwszy zaczął wprowadzać urojone książki do swoich fabuł. Wiem, że gdybym chciał naprawdę skompletować widmową bibliotekę, nie starczyłoby mi życia. [...] Pragnę przedstawić raczej widmowy księgozbiór podręczny oparty o pewien kanon literacki, dzieła modnych dziś autorów i — wreszcie — jakieś odbicie moich przypadkowych lektur (nie ma przecież dwu jednakowych bibliotek) ${ }^{1}$.

Powieści Andrzeja Sapkowskiego nie są typowymi „książkami o książkach”. Jednakże zarówno cykl wiedźmiński, jak i trylogia husycka² obfitują w motywy z nimi związane. Bohaterowie czytają, posiadają bądź gromadzą księgozbiory, a czasem także sami są autorami rozmaitych dzieł. $Z$ wymienianych w poszczególnych tekstach tytułów można by zestawić całkiem obszerną bibliografię. Ten

${ }^{1}$ P. Dunin-Wąsowicz, W widmowej bibliotece, [w:] idem, Widmowa biblioteka, czyli Ksiązki urojone albo Wypisy o xięgach, których nigdy nie było, ale ktoś o nich napisat, Warszawa 1997, s. $4-5$.

${ }^{2}$ Cytaty według wydań: A. Sapkowski, Ostatnie życzenie, Warszawa 1995; idem, Krew elfów, Warszawa 2001; idem, Czas pogardy, Warszawa 2001; idem, Wieża jaskółki, Warszawa 2001; idem, Pani jeziora, Warszawa 2001; idem, Narrenturm, Warszawa 2005; idem, Boży wojownicy, Warszawa 2004; idem, Lux perpetua, Warszawa 2006. W dalszej części artykułu będą one oznaczane w nawiasie za pomocą tytułu książki i numeru strony. 
fakt zachęca do opisania sposobu istnienia rozmaitych tekstów w światach przedstawionych twórcy postaci wiedźmina.

\section{Lektury bohaterów}

Pretekstem do przedstawiania aktywności czytelniczej postaci bywają wątki związane z nauką ${ }^{3}$. Potrzebny jest do tego bohater na tyle młody, by owa edukacja mogła być czytelnikowi zaprezentowana.

Tak jest w przypadku Ciri, przybranej córki Geralta i Yennefer. W scenach nauki dziewczyny w wiedźmińskim siedliszczu Kaer Morhen wspomniana jest księga (ilustrowana) dotycząca walki z potworami. Znajdujemy też nieco wzmianek o lekturach Ciri podczas nauki w świątyni Melitele. Poznawała tam między innymi Dialogi o naturze magii Stammelforda, Mocarstwa żywiołów Giambattisty, Magię naturalna Richerta i Moncka, Świat niewidzialny Jana Bekkera, Tajemnice tajemnic Agnes z Glanville, a nawet „słynną straszną Dhu Dwimmermorc, pełną budzących grozę grawiur". Jako książki niedotyczące magii wymienione są Historia świata i Traktat o życiu. Dziewczyna czytywała również „lżejsze pozycje": Igraszki markiza La Creahme, Królewskie damy Anny Tiller ${ }^{4}$, Niedole mitowania i Czas księżyca — ,zbiory poezji słynnego trubadura Jaskra”. „Popłakała się przy subtelnych, tchnących tajemnicą balladach Essi Daven, zebranych w małym, ślicznie oprawionym tomiku, noszącym tytuł Błękitna perta" (Krew elfów, s. 279-280). Z dziełem traktującym o monstrach Ciri zapoznaje się... podczas wizyty u bankiera. Poproszony przez Yennefer, by dał dziewczynie coś do czytania (co miało zapobiec podsłuchiwaniu rozmowy, było zresztą mało skuteczne), zrazu znajduje on same księgi z dziedziny bankowości. Wreszcie zauważa książkę, która nie wiadomo, skąd się wzięła w banku. „Księga nosiła tytuł Physiologus i była bardzo stara i bardzo podarta. Ciri ostrożnie przewróciła okładkę i kilka stron. Dzieło zaciekawiło ją natychmiast, bo traktowało o zagadkowych potworach i bestiach i było pełne rycin" (Czas pogardy, s. 57).

Wspomnienia tych ksiąg pojawiają się również podczas ucieczki młodej wiedźminki przez pustynię 5 . Napotkane tam stworzenia porównuje ona z rycinami w książkach z Kaer Morhen (Czas pogardy, s. 254), żałuje też, że nie chciało jej się studiować atlasów nieba w świątynnej bibliotece, gdyż taka wiedza przy-

${ }^{3}$ Należy przypomnieć, iż większość ważnych postaci z cyklu wiedźmińskiego to osoby wykształcone. Piszę o tym w innym tekście; zob. K. Walc, „,Machać mieczem może byle dureń, a wiedźminka musi być mądra". Wątki edukacyjno-intelektualno-akademickie w opowieści Andrzeja Sapkowskiego o wiedźminie Geralcie z Rivii, [w:] Dyskursy pogranicza. Wektory literatury. Stanisławowi Uliaszowi w darze, red. J. Pasterska, Z. Ożóg, Rzeszów 2019, s. 592-605.

${ }^{4}$ W Pani jeziora książka została opisana jako romans „o starym królu, młodej królowej i o żądnym władzy księciu pretendencie” (s. 185). Po jednej z wizyt u Króla Olch Ciri „pomyślała, że z Anny Tiller była jednak głupia i egzaltowana grafomanka" (s. 187).

5 Tytułów tych ksiąg czytelnik nie poznaje. 
dałaby się jej podczas nocnej wędrówki (s. 257). Podobne refleksje pojawiają się przy spotkaniu ze stworzeniem, w którym wędrowniczka rozpoznaje jednorożca. $\mathrm{O}$ istotach tych wiedziała dotychczas, że nie istnieją, ponieważ wymarły. Nie było wizerunku jednorożca w wiedźmińskiej księdze.

Czytałam o nich tylko w Księdze mitów w świątyni... Aha, a w Physiologusie, który przeglądałam w banku pana Giancardiego, była ilustracja przedstawiająca jednorożca... Ale jednorożec z ryciny przypominał bardziej kozła niż konia, a jego róg był długi chyba na dwa łokcie. (Czas pogardy, s. 261)

Okazało się także, że księgi łgały w sprawie jednorożców i dziewic (Czas pogardy, s. 264; jednorożec nie wykazywał chęci złożenia głowy na jej podołku), na żadnej ilustracji, w żadnej z wiedźmińskich ksiąg nie było też stwora, który zaatakowałby jednorożca (s. 266).

Znajomość obecnych w chatce pustelnika Vysogoty (byłego uczonego) dzieł ma wykazać, że ranna dziewczyna, którą otoczył opieką, rzeczywiście jest erudytką: czytywała Historię Rodericka de Novembre, przeglądała dzieło pod tytułem Materia medica, zna Herbarius, rozpoznaje księgi wydane przez uniwersytet w Oxenfurcie (Wieża jaskótki, s. 26). Uczonego ostatecznie przekonuje fakt, iż podopieczna potrafi dokończyć zaczęty przez niego cytat ze zbioru elfich baśni i wierszowanych przypowieści (s. 27).

Postaci nie tylko znają rozmaite książki — często porównują się do literackich bohaterów. W trylogii husyckiej pojawiają się niekiedy nie same dzieła, ale ich bohaterowie. Protagonista Reinmar (Reynevan) z Bielawy, jak na wykształconego człowieka przystało, swoje przygody porównuje do perypetii bohaterów słynnych literackich historii miłosnych.

A więc Adela, pomyślał, jadę do Adeli. Na odsiecz Adeli. Jak Tristan do Izoldy, jak Lancelot do Ginewry, jak Garet do Lionessy, jak Guinglain do Esmeraldy, jak Palmerin do Polinardy, jak Medoro do Angeliki. Słowem, trochę głupio i trochę ryzykancko, ba, szaleńczo, lwu prosto w paszczękę. (Narrenturm, s. 80-81)

Następująca niedługo potem przygoda Reinmara ukazuje różnicę między rzeczywistością a przygodami postaci literackich — tym ostatnim pewne rzeczy po prostu się nie zdarzają:

Skryty wśród bagien olsu nad Stobrawą Reynevan odetchnął, ba, poczuł się nawet dumnie i butnie, iście Roland czy Ogier, co okpił i w pole wywiódł prześladujące go hordy Maurów. Buta i dobre samopoczucie opuściły go jednak, gdy spotkała go przygoda zupełnie nierycerska, gdy zdarzyło mu się coś, co nigdy, jeśli wierzyć balladom, nie zdarzyło się Rolandowi, Ogierowi, Astolfowi, Renaltowi z Montalbanu ani Raulowi z Cambrai. Zwyczajnie i całkiem prozaicznie okulał mu koń. (Narrenturm, s. 88)

Do bohaterów ksiąg nawiązuje również bohater cyklu wiedźmińskiego Jarre, młody pisarczyk ze świątyni Melitele, który na ochotnika zgłosił się do wojska: „Muszę przekroczyć ten kanał, jak uczynił to ów mityczny wódz czy bohater, o którym czytałem w zetlałych manuskryptach w świątyni Melitele" (Pani jeziora, s. 206).

Literatura i Kultura Popularna XXVII, Wrocław 2021

(C) for this edition by CNS 
O mijaniu się literatury z prawdą wspomina Samson Miodek ${ }^{6}$ :

Panom trubadurom nie zawsze można dawać wiarę, ich strofy o miłosnych sukcesach u zamężnych dam częściej oddają chęci i marzenia, rzadziej zdarzenia rzeczywiste. Przykładem choćby Marcabru, którego, pomimo nachalnych sugestii, zdecydowanie nic nie łączyło z Eleonorą Akwitańską. Wyolbrzymione są też, moim zdaniem, romanse Bernarta de Ventadorn z panią Alaiz de Montpelier i Raula de Coucy z panią Gabrielą de Fayel. Wątpliwości budzi też Tybald z Szampanii, gdy przechwala się względami Blanki Kastylijskiej. A także Arnold de Mareil, według własnych słów kochanek Adalazji z Béziers, faworyty króla Aragonii. (Narrenturm, s. 268)

Rodzaj lektur wpisany jest w charakterystykę postaci. Podczas swych rozlicznych przygód Reynevan trafia do izby opatki Białego Kościoła. Zastaje ją przy lekturze inkunabułu.

Będący bibliofilem i bibliomanem Reynevan z miejsca, po iluminacjach i rycinach, rozpoznał Psalterium Decem Cordarum Joachima z Fiore. Nie umknęły jego uwadze inne leżące na podorędziu dzieła: Liber Divinorum Operum Hildegardy z Bingen, De amore Dei świętego Bernarda, Teogonia Hezjoda, De ruina ecclesiae Mikołaja de Clemanges. Nie wiedzieć czemu, zupełnie nie zdziwił go w tym towarzystwie podniszczony egzemplarz Necronomiconu. (Boży wojownicy, s. 508)

\section{Księgozbiory}

Wbrew temu, czego czytelnik mógłby się spodziewać, księgozbiory, które poznaje, nie należą do uniwersytetów. Jeśli chodzi o książnicę w Oxenfurcie, poznajemy jedynie jej dach, po którym przemieszcza się Jaskier, chcąc uwolnić się od śledzących go szpiegów. Uczone księgi mogą się znaleźć w najróżniejszych miejscach, choćby w chacie na odludziu (za wątpliwej czystości zasłoną), zamieszkanej przez wspomnianego już Vysogotę z Corvo.

Imponujące księgozbiory posiadają nie tylko uniwersytety i uczeni (także czarodzieje). Olbrzymią pałacową bibliotekę ma w swoim zamku w Toussaint księżna Anarietta, u której gości poszukująca Ciri drużyna ${ }^{7}$. Sceny w bibliotece wpisują się w znany schemat książnicy jako przestrzeni labiryntowej:

Pałacowa biblioteka była rzeczywiście olbrzymia. Sala, w której się mieściła, przewyższała rozmiarami co najmniej dwukrotnie salę rycerską. I miała szklany dach. Dzięki temu było jasno. Geralt podejrzewał jednak, że latem bywało tu przez to cholernie gorąco. Przejścia między półkami i regałami były wąziutkie i ciasne, szedł ostrożnie, by nie postrącać ksiąg. Musiał też przestępować tomy ułożone na podłodze [...]. Środek biblioteki ginął w księgach,

${ }^{6}$ Postać nosi przybrane nazwisko. Działania, wskutek których doszło do połączenia wybitnego umysłu z ciałem mało rozgarniętego osiłka, nie są istotne ze względu na temat rozważań.

${ }^{7}$ Przy okazji czytelnik dowiaduje się, iż uniwersyteckie zbiory nie są dostępne dla wszystkich. Czarodziejka Fringilla Vigo wyjaśnia: „Jestem w Beauclair, bo tu mieści się jeśli nie największa, to najbogatsza biblioteka znanego świata. Poza uniwersyteckimi, ma się rozumieć. Ale uniwersytety są zazdrosne o dostęp do swych półek, a tutaj ja jestem krewną i przyjaciółką Anarietty i wolno mi wszystko" (Pani jeziora, s. 89). 
ułożonych w stosy i słupki. Sporo leżało całkiem bezładnie, pojedynczo lub w malowniczych grupach [...]. Zapuścił się w międzyksiążkowe kaniony i wąwozy. (Pani jeziora, s. 99-100)

Sam księgozbiór zaś został zaprezentowany w sposób dość osobliwy. Spotkanie Geralta i czarodziejki Fringilli Vigo w pałacowej bibliotece, mające służyć poszukiwaniu informacji pomocnej w ratowaniu Ciri, przeobraża się w miłosną schadzkę wśród uczonych dzieł. Scena jest nietypowa z powodu wymienionych tytułów książek — wiadomo dokładnie, na czym leżeli bohaterowie i co na nich spadało. W scenie tej uczestniczą następujące dzieła: Żywoty proroków, traktat medyczny De haemorrhoidibus, Nauka sztuki położnej dla niewiast, O wodach goracych siarczanych, Uwagi o śmierci niechybnej, Prawo hipoteczne, Codex diplomaticus, Geometria wykreślna, Rys o gadach i płazach, Historia wojen, Magazyn wszystkich nauk do szczęśliwego życia potrzebnych, Rolnik doskonaty, O sottysach nieużytecznych i krnąbrnych, Ekonomia albo proste wyluszczenie, jak się tworza, rozdzielaja i spożywaja bogactwa, De larvis scenicis et figuris comicis, Zbiór komend ogólnych dla jazdy, Heraldyka Jana z Attre, Rozmyślania albo medytacje na dni wszystkie całego roku i Rozważania o naturze rzeczy. Takie pomieszanie materii na bibliotecznych półkach tłumaczyć należy być może tym, iż tomy zdjęto z półek w celu zinwentaryzowania i skatalogowania. W końcu Geralt proponuje znalezienie jakiegoś łóżka, gdyż „nie godzi się tak traktować książek” (Pani jeziora, s. 99-103).

Właścicielami godnej podziwu biblioteki są też Codringher i Fenn, prowadzący firmę, którą współcześnie nazwalibyśmy prywatną agencją detektywistyczną, świadczącą także usługi w zakresie pozbywania się niewygodnych osób.

Ruszyli za poskrzypującym fotelem w labirynt między regałami uginającymi się pod ciężarem tomów, których nie powstydziłaby się uniwersytecka biblioteka w Oxenfurcie. Inkunabuły, jak ocenił Geralt, musiały być gromadzone przez kilka pokoleń Codringherów i Fennów. (Czas pogardy, s. 27)

Tytułów znajdujących się tam dzieł czytelnik jednak nie poznaje. W dalszych tomach biblioteka spłonie, a jej właściciele zostaną zamordowani.

Z kolei w trylogii husyckiej pojawia się temat zakazanych książek, oczywistym motywem jest więc ukryta biblioteka. Taką znajdujemy na zapleczu apteki „Pod Archaniołem”.

Za drzwiami była biblioteka. Pełna ksiąg. Oprócz ksiąg, zwojów, papirusów i kilku różnych dziwnych eksponatów nie było tam nic. Na nic więcej nie starczyło miejsca [...]. Sterty inkunabułów leżały po prostu wszędzie, nie można było kroku zrobić, by nie potknąć się o coś takiego jak Summarium philosophicum Nicolasa Flamela, Kitab al-Masuri Razesa, De expositione specierum Morienusa czy De imagine mundi Gerwazego z Tilbury. Przy każdym nieuważnym kroku boleśnie ranił kostkę okuty róg oprawy dzieła tej miary co Semita recta Alberta Wielkiego, Perspectiva Witelona czy Illustria miracula Cezarego z Heisterbachu. Starczyło niebacznie potrącić regał, a na głowę spadała w tumanie kurzu Philosophia de arte occulta Artefiusza, De universo Wilhelma z Owernii lub Opus de natura rerum Tomasza z Cantipré. (Boży wojownicy, s. 76) 
Jedynym, który umiał coś w tym bałaganie odnaleźć, był Szczepan z Drahotusz (pochodzący ze starej morawskiej szlachty zakonnik, augustianin i- oczywiście — czarnoksiężnik) — opiekun księgozbioru. ,[B]ył chodzącym bibliotecznym katalogiem, wiedział o każdej księdze i każdą potrafił szybko zlokalizować w warunkach panującego w pomieszczeniu chaosu była to umiejętność po prostu nieoszacowana" (Boży wojownicy, s. 76-77).

Fakt, iż Reynevan często korzysta z księgozbioru, jest pretekstem do przedstawienia czytelnikowi kolejnych tytułów.

Zainteresowany był ziołolecznictwem i farmaceutyką, a księgozbiór „Archanioła” był pod tym względem prawdziwą kopalnią wiedzy. Oprócz zielników, lekospisów i farmakopej klasycznych i znanych, jak te Dioskuridesa, Strabona, Avicenny, Hildegardy z Bingen czy Mikołaja Przełożonego, biblioteka kryła prawdziwe skarby. Była tam Kitab Sirr al-Asar Gebera, Sefer Ha-Mirkahot Szabbetaia Donnolo, były nieznane dzieła Majmonidesa, Apulejusza, Herrady z Landesbergu — jak też i inne antidotaria, dispensaria i ricettaria, jakich Reynevan nigdy dotąd nie widział i o jakich nigdy nie słyszał. I wątpił, by o nich słyszano na uniwersytetach. (Boży wojownicy, s. 78)

Najosobliwszym chyba obiektem w omawianej prozie jest księga, którą dane było zobaczyć Geraltowi i Jaskrowi w Dolinie Kwiatów — jeden z zamieszkujących wieś rodów od zawsze jest w posiadaniu ,ciężkiego, grubego, obrosłego tłustym kurzem tomiska”, opisującego sposoby walki z potworami. Książka wzbudza zainteresowanie Jaskra.

Pierwsze Runy [...]. Najstarsze pismo używane do czasu wprowadzenia nowoczesnego alfabetu [...]. Ciekawe ryciny i iluminacje. Nieczęsto widzi się coś takiego, Geralt, a jeśli już, to w bibliotekach świątynnych, nie po wsiach na krańcu świata. (Ostatnie życzenie, s. 185)

W opowiadaniu znajdujemy opis dwóch ilustracji. „Widniejący na naddartej stronicy obrazek przedstawiał cętkowaną świnię z rogami w kształcie liry" (s. 186 - wizerunek tura); ,Rycina przedstawiała rozczochrane straszydło na koniu, z ogromnymi ślepiami i jeszcze większymi zębami. W prawej ręce straszydło dzierżyło pokaźny miecz, w lewej wór pieniędzy" (s. 186-187 — jak nietrudno się domyślić, ilustracja przedstawia wiedźmina). Niecodzienny jest też sposób korzystania z księgi — „najstarsza babka zawżdy wie, co w księdze stoi [...]. A tego, co wie, uczy jaką młodą, gdy już jej pora do ziemi” (s. 186). Należy wyjaśnić, że owa staruszka nie umie odczytać księgi — opisy pod ilustracjami zna na pamięć.

\section{Postaci jako autorzy, ale też bohaterowie książek}

Bohaterowie cyklu wiedźmińskiego bywają autorami książek. Przykładowo poeta Jaskier pisze memuary zatytułowane Pół wieku poezji (pierwotny tytuł brzmiał Pięćdziesiąt lat poezji, autor zmienił go jednak za radą Regisa). Osobliwe są dzieje rękopisu — pierwsza wersja została na dworze księżnej Anarietty „pod stertą sukien, majtek i gorsetów” (Pani jeziora, s. 465). Autor zmuszony był

Literatura i Kultura Popularna XXVII, Wrocław 2021

(C) for this edition by CNS 
więc odtworzyć tekst z pamięci. Po latach rękopis znajduje uczony Schliemann w odkrytym przez siebie grobie mężczyzny i kobiety. Niestety, rabusie wykradają i niszczą znalezisko, obawiając się, iż może zawierać czary. Tytuł wymieniany jest jednocześnie wśród lektur adeptki Condwiramurs, co dowodzi, iż książka weszła jednak w obieg czytelniczy (s. 35). Egzemplarz znajdujący się w bibliotece Pani Jeziora to ,wydanie uzupełnione i opatrzone posłowiem przez profesora Everetta Denhoffa Juniora" (s. 54). Natomiast Jarre, jako dojrzały mężczyzna, spisuje dzieje bitwy pod Brenną, w której brał udział.

Warte podkreślenia jest to, że czytelnik ma okazję poznać przynajmniej fragmenty wspomnianych dzieł. W Pani jeziora dotychczasowa trzecioosobowa narracja zmienia się w pierwszoosobową — przytaczane są memuary Jaskra.

Współpracownik szpiega Dijkstry przygotowywał tymczasem dzieło Historia tajnych stużb królewskich, spisana przez Oribasiusa Gianfranco Paolo Reuvena [...]. Niestety autor został zamordowany wraz ze zwierzchnikiem, a rękopis przepadł.

Z motywem książki wiąże się ponadto oryginalny chwyt zastosowany w Pani jeziora. Kontynuacja wątków z poprzednich części przeplata się w tym tomie ze scenami z przyszłości, kiedy przygody bohaterów stały się treścią dzieł omawianych między innymi w szkołach dla czarodziejek i dla kadetów (niektórych opracowań nie wolno było uczniom cytować, gdyż uznano je za nieprawomyślne). Pojawiają się w tych scenach postaci badaczy różnych wersji historii Geralta i Yennefer. Bohaterowie cyklu Sapkowskiego są w tych fragmentach niejako „podwójnie literaccy”. Tytuły dzieł wymienia przybyła do siedziby Pani Jeziora śniączka Condwiramurs:

Znam wszystkie wersje literackie legendy, od Pół wieku poezji Jaskra po Pania jeziora Andrei Ravixa. Znam wielebnego Jarre'a, znam wszystkie opracowania naukowe, a o edycjach popularnych nawet nie wspominam. (Pani jeziora, s. 35)

\section{Księgi uczone, magiczne i zakazane}

Trylogia husycka, jakkolwiek występują w niej nie tylko istoty ludzkie, uprawia się magię itd., jest mocniej od cyklu o wiedźminie umiejscowiona czasowo (XV wiek) i przestrzennie (Śląsk, Czechy). Jest to czas wojen husyckich i działania inkwizycji. Za posiadanie „niewłaściwych” ksiąg można w związku z tym stracić życie. Słowo pisane palą obie strony konfliktu.

Przeszukanie mieszkania Reinmara z Bielawy, po jego ucieczce spowodowanej romansem z mężatką, pokazuje rzecz istotną — pozwala przypuszczać, iż znalezienie heretyckich ksiąg zależało od kompetencji szukającego. Można się obawiać, że w rzeczywistości pozaliterackiej wiele wyroków zapadło z powodu braku owych kompetencji. W Narrenturm rzeczy zarekwirowane Reinmanowi 
(którego przyłapana z nim kochanka, próbując się ratować, oskarżyła o zniewolenie jej czarami) przeglądają Jan Hofrichter, jeden z bogatszych kupców miasta Oleśnicy; Bartłomiej Sachs, burmistrz Oleśnicy; Jakub von Gall, proboszcz od św. Jana Ewangelisty; oraz Łukasz Frydman, złotnik:

— A cóż tu mamy? Prócz Galena, Pliniusza i Strabona? Saladinus de Asculo, Compendium aromatorium. Scribonius Largus, Compositiones medicamentorum. Bartolomeus Angelicus, De proprietatibus rerum, Albertus Magnus, De vegetalibus et plantis... Magnus, ha, przydomek iście godny czarownika. A tu, proszę bardzo, Sabur ben Sahl... Abu Bekr al-Râzi... Poganie! Saraceni!

- Tych Saracenów - wyjaśnił spokojnie, oglądając swe pierścienie, Łukasz Frydman - wykłada się na chrześcijańskich uniwersytetach. Jako medyczne autorytety. A wasz „czarownik” to Albert Wielki, biskup Ratyzbony, uczony teolog.

— Tak powiadacie? Hmmm. Spójrzmy dalej... O! Causae et curae, napisane przez Hildegardę z Bingen. Pewnie czarownica, ta Hildegarda!

— Nie bardzo — uśmiechnął się ksiądz Gall. — Hildegarda z Bingen, prorokini, zwana Sybillą Reńską. Zmarła w aurze świętości.

— Ha. Ale jeśli tak twierdzicie... A cóż to jest? John Gerard, Generall... Historie... of Plantes... Ciekawe, po jakiemu to, po żydowsku chyba. Ale to pewnie kolejny jaki święty. Tu zaś mamy Herbarius, przez Thomasa de Bohemia... (Narrenturm, s. 30-31) ${ }^{8}$

Kilkakrotnie powraca w cyklu motyw kary za posiadanie i czytanie „niewłaściwych” ksiąg. Każe to zastanowić się, za co naprawdę ścigano „winnych”. Zaskakuje w tym kontekście wypowiedź inkwizytora, ujawniająca fakt, iż niekoniecznie chodziło o sprawy wiary:

Mnie, wystaw sobie, nie przeszkadzają księgi, nawet fałszywe i heretyckie. Uważam, wystaw sobie, że żadnych nie powinno się palić, że libri sunt legendi, non comburendi. Że nawet błędne i bałamutne poglądy można szanować, można też, przy odrobinie filozoficznego nastawienia, zauważyć, że naprawdę nikt monopolu nie ma, wiele tez niegdyś okrzykniętych fałszywymi dziś robi za prawdę i odwrotnie. Ale wiara i religia, której bronię, to nie tylko tezy i dogmaty. Wiara i religia, której bronię, to ład społeczny. Zabraknie ładu, nastanie chaos i anarchia [...]. Konkluzja: a niechby sobie Piotr de Bielau i jego komilitoni dysydenci czytywali na zdrowie Wiklefa, Husa, Arnolda z Brescii i Joachima z Fiore. Bo Joachim z Fiore tak, ale nie Fra Dolcino, nie ciompi, nie żakieria. Wiklef tak, ale nie Wat Tyler. Tu kończy się moja tolerancja, Reinmarze. (Narrenturm, s. 542)

\section{O księgach niekoniecznie serio}

Podczas jednego z pobytów w świątyni Melitele Geralt studiuje Historię świata Rodericka de Novembre, ciekawe, choć nieco kontrowersyjne dzieło, w czym

${ }^{8}$ O niebezpieczeństwach związanych ze studiowaniem zakazanych ksiąg wspomina jeden z bohaterów trylogii, niejaki Achilles Czibulka, przywołując tragiczny koniec pana Voighta: „Zamęczyli go, psia ich mać. Za czary i czczenie diabła. Śmiech pusty! Ot, studiował jegomość Zachariasz trochę Picatrix, trochę Necronomicon, Grand Grimoire, czytywał trochę Piotra di Albana, Cecca d'Ascoli i Michała Szkota. Ale czary? Co on się na tych czarach znał. Toć nawet ja w te klocki lepszy" (Lux perpetua, s. 54). 
przybyły Jaskier upatruje przyczyny jego złego nastroju (Ostatnie życzenie, s. 165166). Przy okazji pojawia się znany nie tylko w literaturze motyw - ukrywania alkoholu w bibliotece. Zdaniem Jaskra możliwość sporządzenia rzeczonej kryjówki decydowała o tym, że w Oxenfurcie wielką popularnością cieszyła się geografia: „Atlas świata był większy i łatwiej było za nim ukryć gąsiorek wódki” (s. 166); Geralt natomiast wyciąga alkohol zza książki Arkana magii $i$ alchemii Luniniego i Tyrssa.

Podczas wizyty u pisarczyka Jarre'a Ciri zaczyna wertować leżącą na stole księgę, przeciwko czemu młody „uczony” niespodziewanie protestuje. Wkrótce okazuje się, że nie chodziło o to, iż dziewczyna może mieć brudne ręce. Spomiędzy kart dzieła wypada bowiem erotyczna ilustracja. Książka nosi tytuł Leczenie i uzdrawianie. „Chciałabym wiedzieć, jakie choroby leczy się w taki sposób” — komentuje gość pisarczyka (Krew elfów, s. 250) ${ }^{9}$.

Humorystyczne ujęcie znajdujemy też w trylogii husyckiej, w scenach mających za tło księgozbiór ukryty w aptece „Pod Archaniołem”. Ukazują one szkodliwość ksiąg magicznych w sensie dosłownym:

W całym tym bajzlu można było niechcący wpaść na coś lub przypadkiem dotknąć czegoś, czego nie zalecało się dotykać bez zachowania nadzwyczajnej ostrożności. Zdarzało się bowiem, że grymuary, traktaty o magii i spisy zaklęć rzucały czary same i samoistnie wystarczyło niebacznie ruszyć, stuknąć, puknąć - i nieszczęście gotowe. Szczególnie niebezpieczny był pod tym względem Grand Grimoire, wielce groźnymi potrafiły okazać się też Aldaraia i Lemegeton. Już za drugą wizytą „Pod Archaniołem” Reynevan miał pecha strącić z zawalonego księgami i zwojami stołu grube tomiszcze, którym był ni mniej, ni więcej $L i$ ber de Nyarlathotep.

W tej samej chwili, gdy starożytny i lepki od tłustego kurzu inkunabuł rymnął o podłogę, ściany zadrżały i eksplodowały cztery z sześciu stojących na szafie słojów z homunkulusami. Jeden homunkulus zamienił się w bezpiórego ptaka, drugi w coś w rodzaju ośmiornicy, trzeci w szkarłatnego i agresywnego skorpiona, a czwarty w zminiaturyzowanego papieża w szatach pontyfikalnych. Zanim ktokolwiek zdołał cokolwiek przedsięwziąć, wszystkie cztery rozpłynęły się w zieloną i obrzydliwie cuchnącą maź, przy czym karłowaty papież zdążył jeszcze wyskrzeczeć: „Beati immaculati, Cthulhu fhtagn!”. Było od cholery sprzątania. (Boży wojownicy, s. 76-77)

Goszcząca u Pani Jeziora śniączka przychylniejszym okiem patrzy na swojego gburowatego przewoźnika, którym okazał się Król Rybak, małżonek Nimue, kiedy słyszy o jego nałogu czytania. Jedyne, czego dowiadujemy się o jego lekturach, to tytuł dzieła czytanego... w klozecie — jest to Speculum aureum (Pani jeziora, s. 34).

${ }^{9}$ W Pani jeziora pojawia się wiadomość o księdze, którą niekoniecznie kojarzymy ze świątynną biblioteką. Przybyła na spotkanie z Królem Olch Ciri zastaje go nad księgą zawierającą najwyraźniej ilustracje pozycji erotycznych. „W świątynnej bibliotece w Ellander widziała kilka podobnych dzieł. Ale z księgą Króla Olch tamte nie mogły konkurować, ani bogactwem i rozmaitością pozycji, ani artyzmem ich zobrazowania" (s. 187-188). 


\section{Miejsce książki w świecie przedstawionym}

Motyw „książki (niekiedy niemającej odpowiednika w rzeczywistości pozaliterackiej) w książce" to zjawisko o długiej tradycji. Z dzieł dawnych wspomnieć należy chociażby Gargantue i Pantagruela Rabelais'go czy Don Kichota Cervantesa (jednym ze źródeł wiedzy o przygodach rycerza z Manczy jest ,arabski szpargał kupiony za pół reala na rynku w Toledo" ${ }^{10}$ ). Z literatury współczesnej prozę Borgesa (pierwszym skojarzeniem będzie oczywiście biblioteka Babel, motyw fikcyjnego dzieła pojawia się również w licznych opowiadaniach). Z literatury polskiej zaś wypada przywołać bibliotekę ze stacji kosmicznej w Solaris Stanisława Lema, w której zgromadzono cały „stan wiedzy” o planecie, czy tegoż autora Bibliotekę XXI wieku, zawierającą recenzje fikcyjnych tekstów. Z literatury najnowszej przypomina się chociażby Cmentarz Zapomnianych Książek z cyklu Carlosa Ruiza Zafóna. To, rzecz jasna, tylko nieliczne przykłady.

Paweł Dunin-Wąsowicz o fikcyjnych utworach literackich wyraża się następująco:

Skądinąd bardzo często cytowany tytuł pełni wyłącznie rolę rekwizytu. Weźmy na przykład Berre-fixe Roberta de Passaventa z Fatszerzy Andre Gide'a. Czy dzięki informacjom o istnieniu tego utworu wzbogacona zostaje nasza wiedza o jego twórcy? Absolutnie nie ${ }^{11}$.

Proza Sapkowskiego zdaje się przeczyć tym ustaleniom. Bycie autorem książki czy znajomość dzieł są istotnym elementem w konstruowaniu postaci. Czytelnik poznaje zatem przynajmniej fragmenty ich twórczości ${ }^{12}$.

W świecie przedstawionym obu omawianych cykli książka jest czymś ważnym i cennym (Condwiramurs kupiła pierwszą książkę opisującą perypetie Geralta i Yennefer za utarg ze sprzedaży własnoręcznie zebranych jagód - Pani jeziora, s. 23). Znajomość uczonych dzieł czyni postać wiarygodną. W związku z tym w scenach trylogii husyckiej pojawiają się książki o obcych i trudnych do wymówienia tytułach (będące swego rodzaju „przypisami” do poszczególnych scen). Stwierdzając u zakonnika letarg, Reynevan wymienia dzieła o tym traktujące: Canon medicinae Avicenny, Razesa i Averroesa (Narrenturm, s. 202). By zaś udowodnić swe kompetencje, Szarlej przywołuje Etymologiae i De natura rerum, Dialogus Magnus visionum atque miraculorum Cezarego z Heisterbachu, De universo Rabana Maura, arcybiskupa mogunckiego (s. 203). Kiedy indziej tenże bohater wymienia dzieła, które powinien znać egzorcysta: Dialogus de energia et operatione daemonum Michała Psellosa, Exorcisandis obsessis a daemonio pa-

${ }^{10}$ P. Dunin-Wąsowicz, Widmowa biblioteka..., s. 114.

11 P. Dunin-Wąsowicz, $W$ widmowej bibliotece..., s. 6.

12 Cytaty z dzieł bohaterów pojawiają się także w mottach, które w przypadku cyklu wiedźmińskiego szczegółowo omówiła Magdalena Roszczynialska, Sztuka fantasy Andrzeja Sapkowskiego. Problemy poetyki, Kraków 2009, rozdz. Palimpsesty. Problematyka motta w cyklu wiedźmińskim, s. 51-77. 
pieża Leona III, Picatrix ,przetłumaczony z arabskiego przez Alfonsa Mądrego, uczonego króla Leonu i Kastylii", Orationes contra daemoniacum i Flagellum daemonum, Księgę tajemnic Henocha, ,ale tu nie ma się czym chwalić, to znają wszyscy" (s. 305). Dowiadujemy się również, jakie pozycje traktują o istotach z innych wymiarów (Zohar, De universo Rabana Maura, Duns Scotus — s. 227). Podczas rozmów o miłości wymieniani są Petrarka i Wolfram von Eschenbach (s. 218).

Pisarczyk Jarre, pytany przez Ciri, czy spodziewa się wojny, wymienia czytane przez siebie dzieła z dziedziny wojskowości, pozwalające mu na wnioskowanie przez analogię: Historię wojen, napisaną przez marszałka Pelligrama, Strategię diuka de Ruytera czy też Przewagi elearów redańskich Bronibora (Krew elfów, s. 249).

Także w czasie dyskusji o wampirze Jaskier powołuje się na specjalistyczną księgę, zaopatrzoną w ,grawiury, przedstawiające ślady ukąszeń wampira na łabędzich szyjach dziewic" (Chrzest ognia, s. 146).

Należy w tym miejscu wspomnieć o istotnej różnicy między oboma cyklami. W historii Geralta z Rivii mamy do czynienia głównie z księgami fikcyjnymi. Rzec można - wszystko rozgrywa się w obrębie świata przedstawionego i do niego przynależy. Inaczej jest w trylogii husyckiej. Przytaczane tam księgi to dzieła autentyczne, choć w czasie, kiedy toczy się akcja powieści, niektóre z nich jeszcze nie istniały, o czym zresztą wspomina autor w przypisach. $Z$ jednym wyjątkiem. Jest nim Necronomicon — książka wymyślona przez Howarda Phillipsa Lovecraf$\operatorname{ta}^{13}$. O dziele tym autorzy wstępu do Historii Necronomiconu Lovecrafta piszą:

Nazwa ta już na zawsze będzie związana z twórczością Lovecrafta, i to nie tylko z powodów literacko-mitologicznych. Na oddzielne zbadanie przez socjologów kultury masowej (współczesnego mitu) zasługuje fakt, iż na przestrzeni dziesięcioleci wokół „bluźnierczej księgi” narosło tak wiele opowieści i legend, że po dziś wielu wierzy w jej prawdziwość. Istnieją sekretne stowarzyszenia, ezoteryczne kościoły... O niezwykłości Necronomiconu niech zaświadczy i to, iż wciąż stanowi inspirację dla całej rzeszy pisarzy, malarzy, filmowców, twórców gier komputerowych i fabularnych... [...] Księga sama w sobie stała się archetypem ${ }^{14}$.

Poza przywołanymi przykładami - czuwający nocą przy grobie brata Reynevan marzy, by mieć przy sobie Necronomicon lub Lemegeton (Narrenturm, s. 139). Rzadki to przypadek, kiedy nieistniejące dzieło jest powszechnie czytane.

Analizowane cykle nie są jedynymi tekstami Sapkowskiego, w których książka odgrywa znaczącą rolę. W powieści Żmija ${ }^{15}$ uczestnicy wojny w Afganistanie dyskusję nad sytuacją, w jakiej się znaleźli, przeplatają cytatami z Dostojewskie-

13 Zob. P. Dunin-Wąsowicz, Widmowa biblioteka..., s. 253-255; I. Barczak, Księgi zakazane w mitologii Cthulhu, Carpenoctem.pl, https://bit.ly/3xSnuf9 (dostęp: 21.06.2021). Jako ciekawostkę można podać ukazanie się w 2011 roku, nakładem wrocławskiego Wydawnictwa XXL, publikacji Necronomicon, czyli Ksiega umartego prawa, napisany przez Abdul El Hazzereda.

14 W. Chwiłkowski, J. Cichocki, Howard Phillips Lovecraft, [w:] H.P. Lovecraft, Historia Necronomiconu, przeł. J. Drewnowski, A. Ledwożyw, R. Lipski, Warszawa 2002, s. 17-18.

15 A. Sapkowski, Żmija, Warszawa 2009. 
go, Gogola i Orwella (s. 113). Wzmianka o tym ostatnim pojawia się w rozmowie głównego bohatera z majorem Sawieliewem jako odmiana motywu „ksiąg zakazanych”: „czytania George'a Orwella w naszym kraju nie zaleca się, choć obecnie za myślozbrodnię to już w zasadzie nie uchodzi" (s. 122). Z kolei w opowiadaniu Złote popoludnie ${ }^{16}$, nawiązującym do Alicji w krainie czarów, Alicja Liddell, chcąc udowodnić, że pismo „Young Misses Magazine” nie było jej jedyną lekturą, informuje, że czytała jeszcze Robinsona Crusoe i sir Waltera Scotta (s. 228). Uczestnicy herbatki u Kapelusznika, komentując opowieść Alicji, powołują się na autorytet Freuda i Bettelheima (s. 226). Na koniec wskażmy, że w opowiadaniu Tandaradei! $!^{17}$ istotną rolę odgrywa poezja średniowiecznego poety i trubadura Walthera von der Vogelweide. Pojawia się też motyw „ukrytej” (tym razem w tekturowych okładkach encyklopedii Orgelbranda) ksiąg magicznych w domu, do którego przez przypadek weszła bohaterka utworu (s. 102-103).

Warto byłoby zastanowić się nad jeszcze jednym faktem: dlaczego księgi w omawianej prozie są tak często brudne i zniszczone, a w księgozbiorach panuje bałagan?

\section{Bibliografia}

\section{Teksty}

Necronomicon, czyli Księga umartego prawa, napisany przez Abdul El Hazzareda, Wydawnictwo XXL, Wrocław 2011.

Sapkowski A., Boży bojownicy, superNOWA, Warszawa 2004.

Sapkowski A., Czas pogardy, superNOWA, Warszawa 2001.

Sapkowski A., Krew elfów, superNOWA, Warszawa 2001.

Sapkowski A., Lux perpetua, superNOWA, Warszawa 2006.

Sapkowski A., Narrenturm, superNOWA, Warszawa 2005.

Sapkowski A., Ostatnie życzenie, superNOWA, Warszawa 1995.

Sapkowski A., Pani jeziora, superNOWA, Warszawa 2001.

Sapkowski A., Tandaradei!, [w:] idem, Maladie i inne opowiadania, superNOWA, Warszawa 2012. Sapkowski A., Wieża jaskótki, superNOWA, Warszawa 2001.

Sapkowski A., Złote popotudnie, [w:] idem, Maladie i inne opowiadania, superNOWA, Warszawa 2012.

Sapkowski A., Żmija, superNOWA, Warszawa 2009.

\section{Opracowania}

Barczak I., Księgi zakazane w mitologii Cthulhu, Carpenoctem.pl, https://bit.ly/3xSnuf9 (dostęp: 21.06.2021).

16 A. Sapkowski, Złote popotudnie, [w:] idem, Maladie i inne opowiadania, Warszawa 2012.

17 A. Sapkowski, Tandaradei!, [w:] idem, Maladie... 
Chwiłkowski W., Cichocki J., Howard Phillips Lovecraft, [w:] H.P. Lovecraft, Historia Necronomiconu, przeł. J. Drewnowski, A. Ledwożyw, R. Lipski, Copernicus Corporation, Warszawa 2002.

Dunin-Wąsowicz P., $W$ widmowej bibliotece, [w:] idem, Widmowa biblioteka, czyli Książki urojone albo Wypisy o xięgach, których nigdy nie było, ale ktoś o nich napisat, Świat Książki-Lampa i Iskra Boża, Warszawa 1997.

Roszczynialska M., Sztuka fantasy Andrzeja Sapkowskiego. Problemy poetyki, Wydawnictwo Naukowe Uniwersytetu Pedagogicznego, Kraków 2009.

Walc K., „Machać mieczem może byle dureń, a wiedźminka musi być mądra”. Wątki edukacyjno-intelektualno-akademickie w opowieści Andrzeje Sapkowskiego o wiedźminie Geralcie z Rivii, [w:] Dyskursy pogranicza. Wektory literatury. Stanistawowi Uliaszowi w darze, red. J. Pasterska, Z. Ożóg, Wydawnictwo Uniwersytetu Rzeszowskiego, Rzeszów 2019.

\title{
A Few Remarks on the Books, Not Only Books of Knowledge, in Andrzej Sapkowski's Prose
}

\author{
Summary
}

Andrzej Sapkowski's novels are not typical "books about books". However, both The Witcher cycle and The Hussite Trilogy abound in themes associated with them. The characters read, own book collections, they themselves are authors of various works. From the titles listed in individual texts, one could compile quite an extensive bibliography. This fact encourages a description of the way various texts exist in the world presented by the creator of The Witcher.

Education of a young protagonist is a good opportunity to present books one reads, and the use of this readings in further life.

Contrary to what the reader would expect, the book collections he learns about do not belong to universities. As for the library in Oxenfurt, we only know its roof, which is used by poet Jaskier, wanting to free himself from the spies following him. The scholarly books can be found in various places, even in a hut in a remote area (behind a curtain of dubious purity), inhabited by the scholar in exile - Vysogota from Corvo.

Not only universities and scholars (including wizards) have impressive book collections. Duchess Anarietta, who hosts the witcher and his team, has a huge library in her palace in Toussaint.

The subject of banned books appears in The Hussite Trilogy, so the hidden library motif is the obvious motive.

Some protagonists of The Witcher cycle are authors of books. It is worth emphasizing that the reader has the opportunity to learn at least fragments of the mentioned works. They are also read by other characters. Quotes from the characters' works also appear in mottoes. 
Literatura i Kultura Popularna XXVII, Wrocław 2021

(C) for this edition by CNS 